\title{
Seasonal Variability of Waves Within the Indonesian Seas and Its Relation With the Monsoon Wind
}

\author{
Purwanto ${ }^{1,2 *}$, Denny Nugroho Sugianto ${ }^{1,3}$, Muhammad Zainuri13, Galuh Permatasari1, \\ Warsito Atmodjo1, Baskoro Rochaddi ${ }^{1}$, Aris Ismanto ${ }^{1}$, Parichat Wetchayont ${ }^{4}$, \\ Anindya Wirasatriya ${ }^{1,3}$ \\ ${ }^{1}$ Department of Oceanography, Faculty of Fisheries and Marine Science, Diponegoro University \\ ${ }^{2}$ Doctoral Program of Marine Science, Diponegoro University \\ ${ }^{3}$ Center for Coastal Rehabilitation and Disaster Mitigation Studies (CoREM), Diponegoro University \\ Jl. Prof. H. Soedarto, SH, Tembalang, Semarang, Central Java, 50275 Indonesia \\ ${ }^{4}$ Department of Geography, Faculty of Social Sciences, Srinakharinwirot University \\ 8114 Sukhumvit 23, Bangkok, Thailand \\ Email: purwantoirh@lecturer.undip.ac.id
}

\begin{abstract}
The previous studies have simulated the variability of the wave within the Indonesian seas which showed that the variability of wave follows the seasonal pattern. However, their analysis only consider the influence of local wind forcings. The bias and error of their simulated wave were also unclear. In the present study, we investigate the variability of wave within the Indonesian seas and its relation with the surface wind speed using the combination of reanalysis and remote sensing data with high accuracies. We split the analysis into swell and wind wave to obtain the influence of local and remote wind forcings. We show that at the inner seas (i.e., the South China Sea, Java Sea, Flores Sea, Banda Sea and Arafura Sea), the variability of significant wave height (SWH) is majorly influenced by the variability of the speed of monsoon wind. The maximum SWH during Northwest monsoon (NWM) season is located at the South China Sea while during Southeast monsoon (SEM) season is at Arafura Sea. This indicates that the wind wave (sea) is dominant at the inner seas. At the open seas (i.e., Pacific Ocean and Indian Ocean) the variability of SWH less corresponds to the the speed of monsoon wind. The remote wind forcings control the wave variability in the open ocean area. This indicates that swell is dominant at the open seas. In general, the magnitude of $\mathrm{SWH}_{\text {swell }}$ is also more than $\mathrm{SWH}_{\text {sea }}$ within the Indonesian seas.
\end{abstract}

Keywords: significant wave height, swell, wind wave, surface wind, Indonesian seas

\section{Introduction}

Indonesia is a maritime country, consists of 17,499 islands with 2.7 million $\mathrm{km}^{2}$ sea area (Hadi 2007). Located between 2 continents i.e., Asia and Australia and between 2 oceans i.e., Pacific Ocean and Indian Ocean, Indonesia is strongly influenced by the monsoon wind which changes its direction every season (e.g., Susanto et al., 2006). During DecemberFebruary, northwesterly wind blows from Eurasian continent to Australia Continent; carries moist and warm air over the Indonesia. This season is known as winter monsoon or Northwest monsoon (NWM). Conversely, During June-August, southeasterly wind blows from Australia to Eurasian Continent carrying dry and warm air over Indonesian region known as southeast monsoon (SEM) season (Setiawan and Habibie 2010; Alifdini et al. 2021). The transition period are from March to May (Transition 1) and September to November (Transition 2). This monsoon wind affect the seasonal variability of ocean parameters within the Indonesian Seas in general.
One of the ocean parameters which is influenced by wind is wave. As a country with $70 \%$ area is sea area, understanding the wave characteristics is very important to guarantee the safety of ships transportation within the islands connections since the ship transportation is susceptible for the high waves. The investigation of the high wave prone areas of Indonesia has been conducted by Kurniawan et al. (2011, 2012) using Windwaves-05 model which is developed from MRI-II model from Japan. Kurniawan et al. (2011) showed the close relation between the ocean wave variations and seasonal wind patterns over Indonesia. During the NWM and SEM seasons, mean of wave height is higher than during the transition period. Furthermore, by applying the wave height threshold of more than 2 m, Kurniawan et al. (2012) found that the high waves prone areas during SEM season are generally wider than during NWM season. During transition season, the high wave prone areas within the Indonesian Seas are only identified at part of the South China Sea, Pacific Ocean and Indian Ocean, particularly southern part of Java to Bengkulu. 
Further investigation by Habibi et al. (2018) using WAVEWATCH-III model also shows the same tendency. The variability of the significant wave height (SWH) follows the monsoon cycle. The highest wave height is in found during the peak of SEM and NWM seasons with the lowest variance. This indicates the stability of the high SWH during SEM and NWM seasons. In terms of spatial distribution, the SWH in the open seas is higher than in the inner seas. The wave height variability at the open seas is also more stable than the inner seas. The most stable area is in Indian Oceans followed by Pacific Oceans and South China Sea, while the most unstable region is in Tomini Bay following by Flores Sea and Malaka Strait.

Although the seasonal variability has been investigated by Kurniawan et al. (2011, 2012) and Habibi et al. (2018), the bias and error of their simulated wave were unclear. In the present study we investigate the seasonal variability of wave within the Indonesian seas using reanalyses product from Copernicus Marine Environment Monitoring Service (CMEMS) with the bias and Root Mean Square Deviation (RMSD) against the in-situ measurement for the global ocean is $-0.05 \mathrm{~m}$ and $0.34 \mathrm{~m}$, respectively. For the tropics, the bias and RMSD are much better, i.e., $-0.02 \mathrm{~m}$ and $0.24 \mathrm{~m}$, respectively (Law-Chune et al. 2020). We also used the high resolution of satellite based surface wind data to conduct the further investigation of the relation between the variability of wave with the surface wind by splitting the analysis of wave into swell and wind wave which was missed in the previous studies.

\section{Materials and Methods}

A set of Global Wave Reanalysis data (GLOBAL_REANALYSIS_WAV_001_032) from Marine Copernicus was used in this study (Law-Chune, 2019). We took 3 hourly SWH, significant swell wave height (SWH $\mathrm{SWell}_{\text {swe }}$, and significant wind wave height $\left(\mathrm{SWH}_{\text {sea }}\right)$ data with the period of observation of 2007 to 2019. $\mathrm{SWH}$ is the average of the $1 / 3$ highest wave in a certain period. The grid interval of this dataset is $0.2^{\circ} \times 0.2^{\circ}$. This study also used semi-daily Advanced Scatterometer (ASCAT) for surface wind data (FigaSaldana et al., 2002) which also has good accuracy for open seas and coastal areas (Verhoef and Stoffelen, 2013). The spatial resolution of this dataset is $0.125^{\circ} \times 0.125^{\circ}$.

To obtain the seasonal variation of waves, the analysis is based on the monthly climatology mean. Thus, all dataset were composited into monthly and monthly climatology following (Wirasatriya et al. 2017).

$$
\bar{X}(x, y)=\frac{1}{n} \sum_{i=1}^{n} x_{i}(x, y, t)
$$

where $\bar{X}(x, y)$ is the monthly mean value or monthly climatology value at position $(x, y), x_{i}(x, y, t)$ is $i^{\text {th }}$ value of the data at $(x, y)$ position and time t. Next, $n$ is the number of data in one month period and the number of monthly data in one period of climatology (i.e., from 2007 to 2019 = 13 data) for monthly calculation and monthly climatology calculation, respectively. Furthermore, $x_{i}$ is excluded in the calculation if that pixel is hollow.

\section{Result and Discussion}

\section{Seasonal variation of wave within the Indonesian Seas}

From the climatological mean from 2007 to 2019 (Figure 1a.), generally, the SWHs in the Java Sea, Banda Sea, Flores Sea and Sulawesi Sea are higher than the SWHs in the Indian Ocean, Pacific Ocean, South China Sea and Arafura Sea. This may correspond to the distribution of the surface wind speed (Figure 1b.). The maximum SWH occurs during SEM season (Figure 2.). Indian Ocean becomes the area with the highest SWH reaching more than $2.5 \mathrm{~m}$ during SEM season. At the Arafura Sea, the SWH also can reach more than $1.5 \mathrm{~m}-2 \mathrm{~m}$ (Figure 2c.). This corresponds to the strong southeasterly wind from Australia (Figure 3c) as also reported by Alifdini et al. (2021). This strong wind propagates to the Banda Sea and Java Sea which makes the SWH in this area can reach more than $1 \mathrm{~m}$. At the South China Sea, where the wind speed is weaker, the SWH cannot reach $1 \mathrm{~m}$. At the Pacific Ocean, the $\mathrm{SWH}$ still can reach $1 \mathrm{~m}$ under the low wind speed condition.

During the NWM season, the SWH is lower than the SEM season in general. However, the area with the SWH $>2 \mathrm{~m}$ are found at the South China Sea, Pacific Ocean and Indian Ocean (Figure 2a.). At the South China Sea, the high SWH corresponds to the strong NWM wind blowing from Asia. Along the monsoon wind path (Java Sea, Flores Sea and Arafura Sea) the SWH still can reach $1 \mathrm{~m}$. At the Indian Ocean, the SWH remains high under the low wind speed condition (Figure 3a.).

The lowest SWH occurs during both Transition season. Within the inner seas, the SWH cannot reach $0.5 \mathrm{~m}$ (Figure 2b,d.). This low SWH corresponds to the low wind speed occurs during both Transition season. However, SWH during the Transition II is a little higher than that during the Transition II since the wind speed during the Transition II is higher than that during the Transition I. At the Indian Ocean and Pacific Ocean, $\mathrm{SWH}$ can reach more than $1.5 \mathrm{~m}$ under the condition 
of low wind speed. Thus The SWH in these areas are not influence solely by the local wind.

To give better understanding about the relationship between SWH and wind speed, we sampled 5 areas representing the wave height classification areas made by Hardjono (2018) i.e., South China Sea and Pacific Ocean which represent northern equatorial area; Arafura Sea, Indian Ocean which represent the southern equatorial area; and Java Sea which represents the inner seas (Figure 1a.) to plot the temporal variation as shown in Figure 4. This figure shows that the fluctuation of SWHs at the South China Sea, Arafura Sea and Java Sea follow the wind speed fluctuation. As shown by Purbani (2019), the stronger wind speed the higher wave is formed. At the South China Sea, the highest significant wave and strongest wind speed height occur in January.
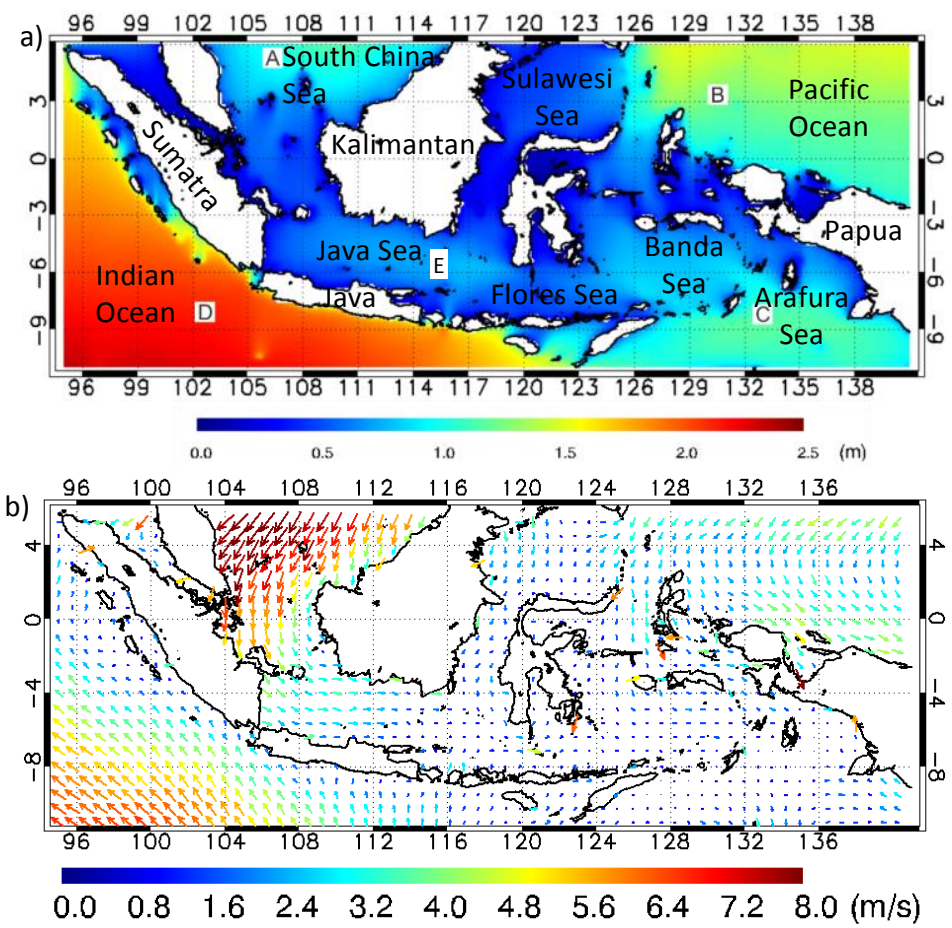

Figure 1. Climatological mean (2007-2019) of a) SWH and b) surface wind within the Indonesian seas. A, B, C, D, and E in Figure. a) represent the chosen points for time series analysis shown in Figure 4 and 5.

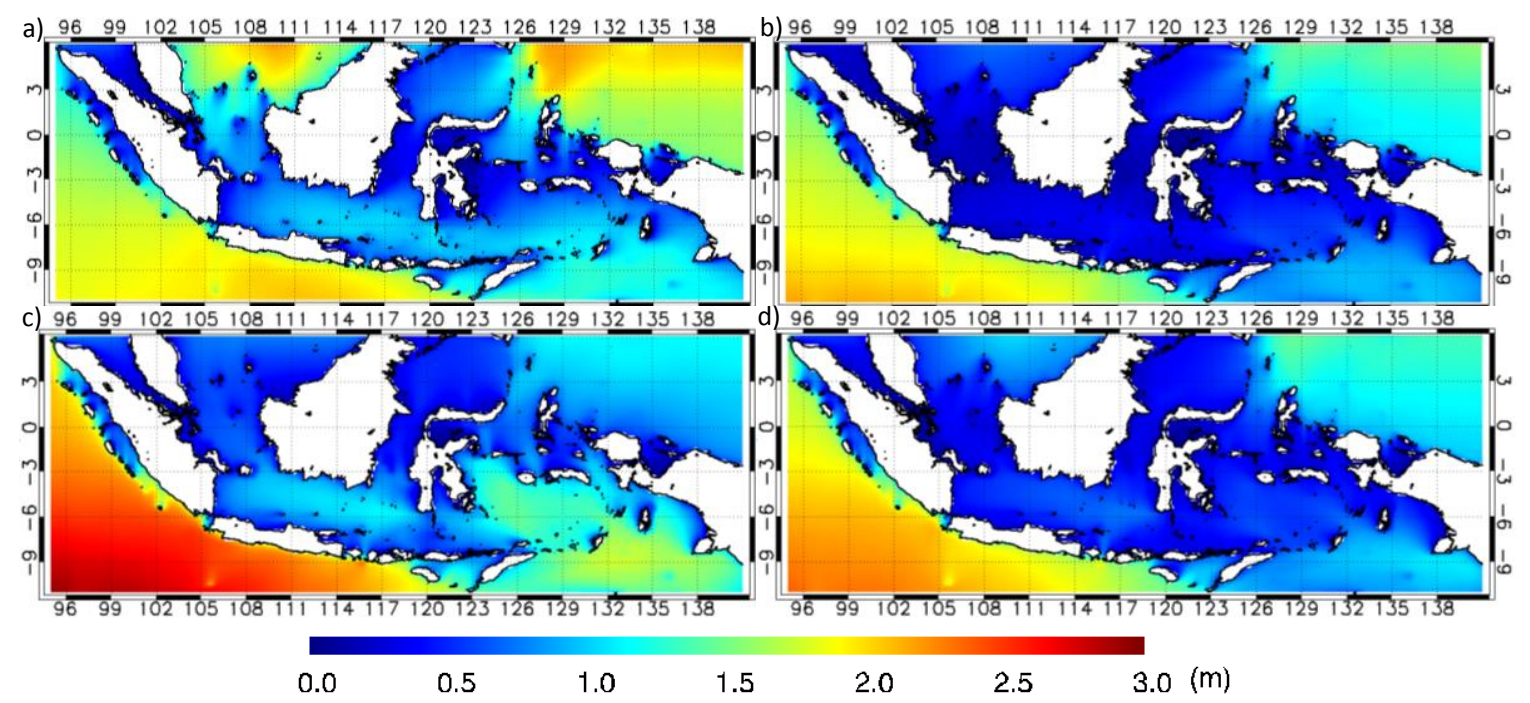

Figure 2. Monthly climatology of the SWH (2007-2019) in a) January, b) April, c) July, and d) October which represent the NWM season, Transition I season, SEM season, and Transition II season, respectively. 


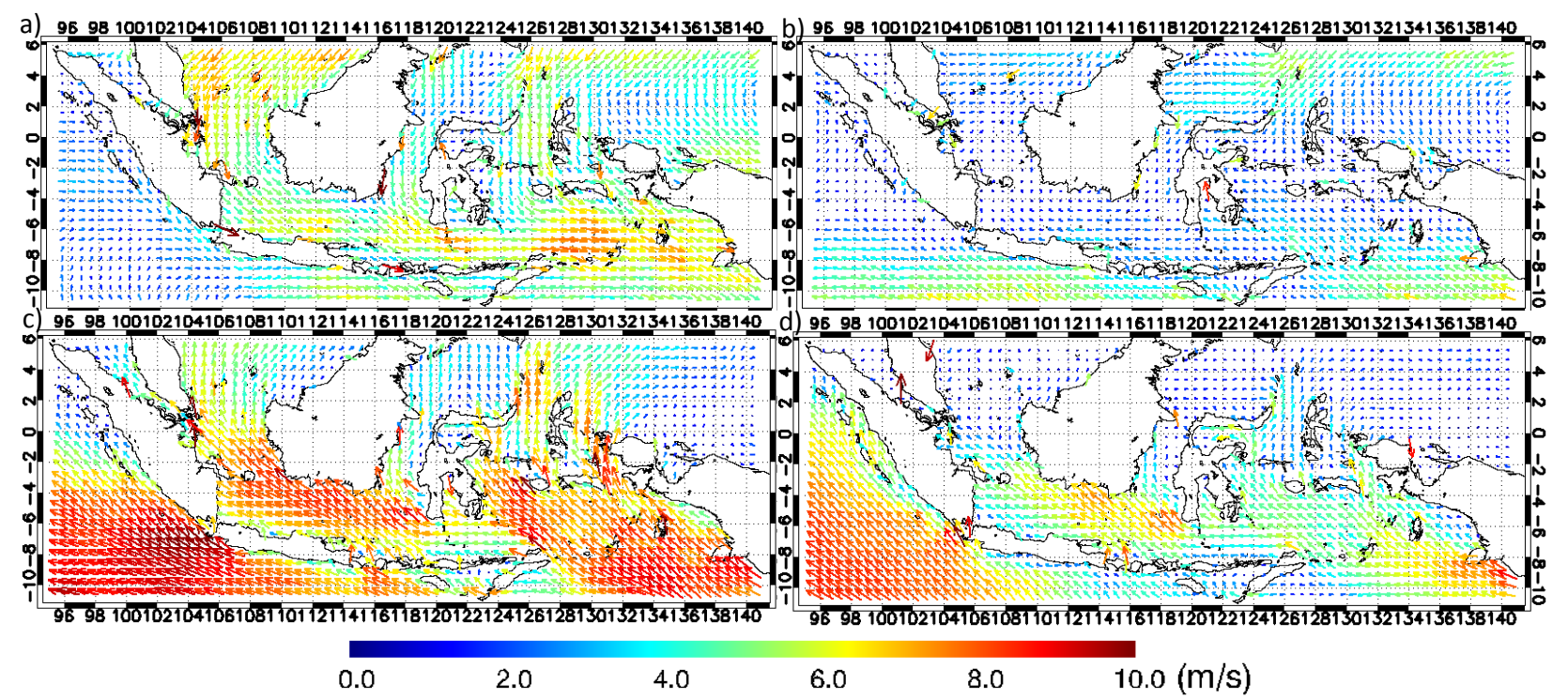

Figure 3. The same as Figure 2 but for monthly climatology of the surface wind

a)

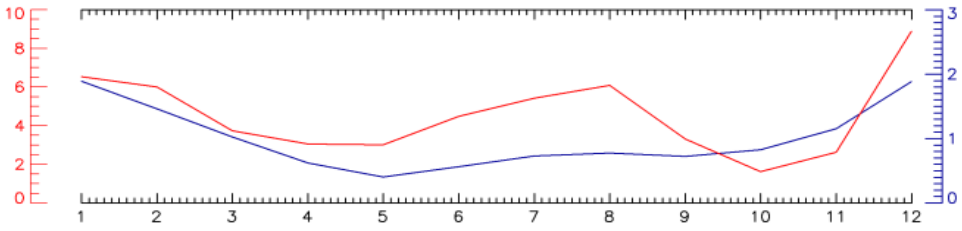

b)

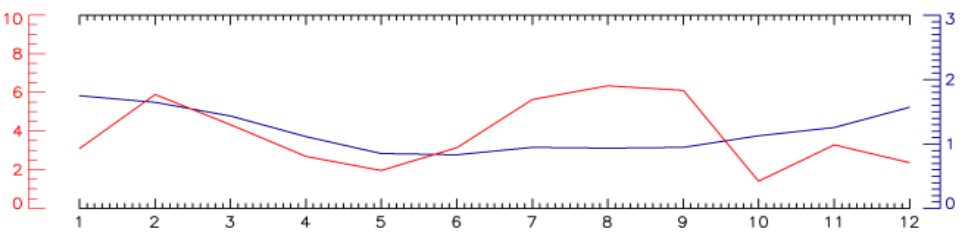

c)

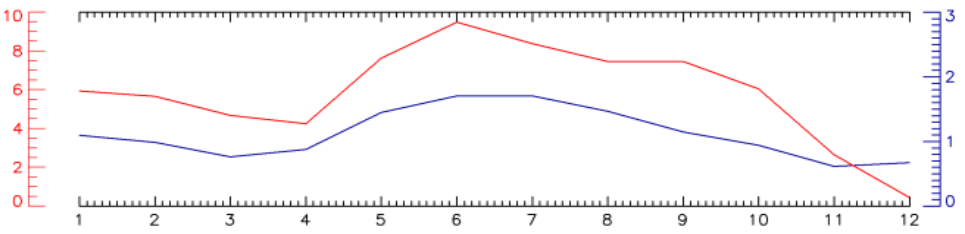

d)

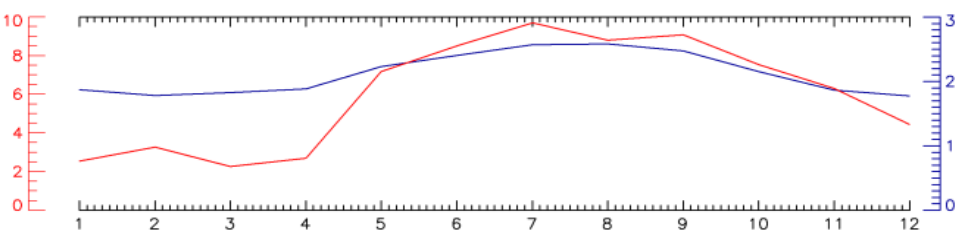

e)

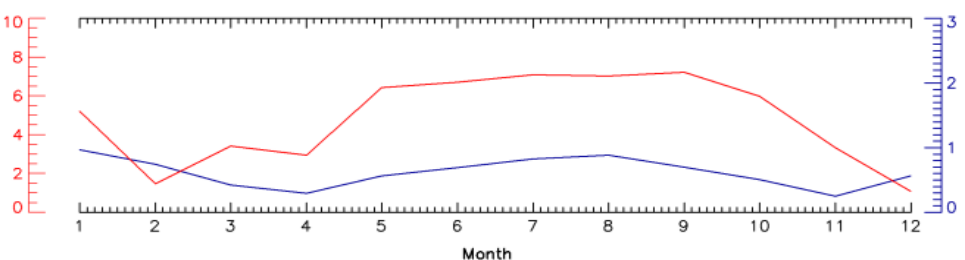

- Wind Speed $(\mathrm{m} / \mathrm{s})$

- Wave Height ( $m$ )

Figure. 4. Temporal variation of the SWH at a) South China Sea, b) Pacific Ocean, c) Arafura Sea, d) Indian Ocean and e) Java Sea as denoted by the points A, B, C, D, and E in Figure $1 \mathrm{a}$. 
Furthermore, at the peak of SEM season i.e., August, the peak of southerly wind speed is only half of the peak of northerly wind speed in January. This makes the climatological mean of wind speed is high with southward direction but the climatological mean of SWH is not so high. At the Arafura Sea, the relation between wind speed and SWH is more robust than at the South China Sea. The maximum SWH and wind speed occur during SEM season. At the Java Sea the maximum SWH occurs during NWM season. These results show that the variability of SWH at the inner seas follows the variability of the monsoon wind which is consistent with the simulation of Kurniawan et al. (2011) and Habibi et al. (2018).

In contrast with the fluctuation in the inner seas, the fluctuation of the SWH at the Pacific Ocean and Indian Ocean do not follow the wind speed fluctuation. At the Pacific Ocean, the incongruity between wind speed and SWH is shown by the highest (lowest) wind speed during SEM (NWM) season which is followed by the lowest (highest) SWH. At the Indian Ocean, the SWH remains higher than $1.5 \mathrm{~m}$ throughout the year although the weak wind by less than 3 $\mathrm{m} / \mathrm{s}$ is identified in January - April. To explain these incongruities, we split the analysis of the SWH into the $\mathrm{SWH}_{\text {swell }}$ and the $\mathrm{SWH}_{\text {sea. }}$.

\section{The analysis of significant swell wave height and the significant wind wave height}

Figure 5 shows the temporal variation of the $\mathrm{SWH}_{\text {swell }}$ and $\mathrm{SWH}_{\text {sea }}$ at South China Sea, Pacific Ocean, Arafura Sea, Indian Ocean and Java Sea. At the South China Sea, Arafura Sea and Java Sea, the variability of the $\mathrm{SWH}_{\text {swell }}$ and the $\mathrm{SWH}_{\text {sea }}$ follow the variability of wind speed. At the Java Sea and Arafura Sea, the $\mathrm{SWH}_{\text {sea }}$ is lower than the $\mathrm{SWH}_{\text {swell }}$ in general.

a)

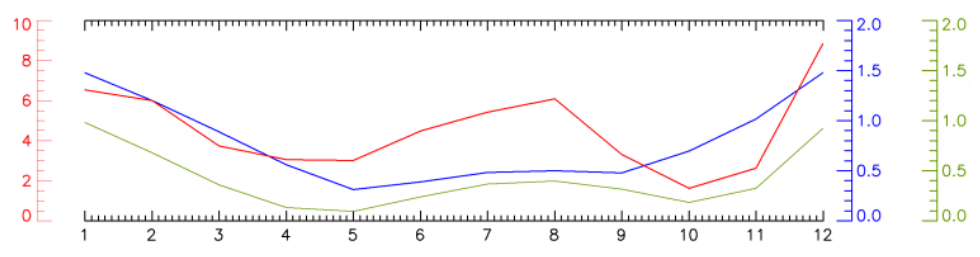

b)

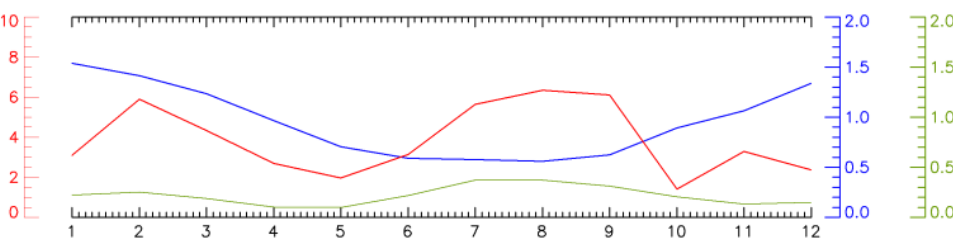

c)

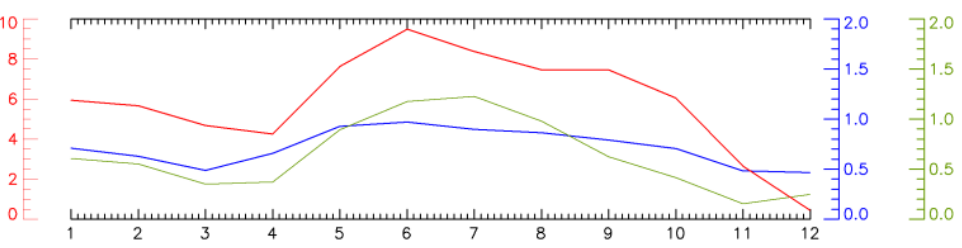

d)

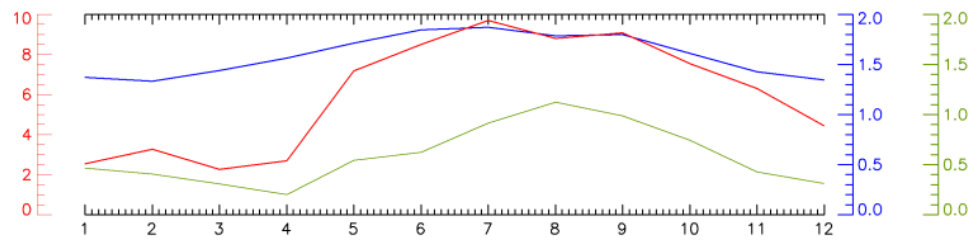

e)

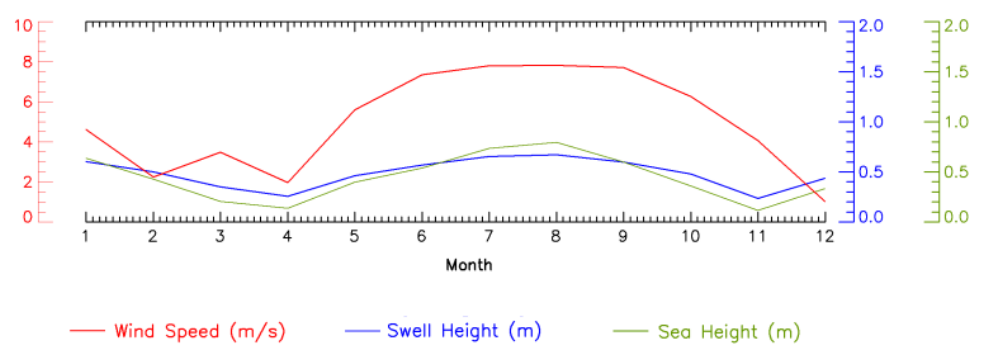

Figure 5. The same as Figure. 4 but for the significant swell wave height and significant wind wave height. 


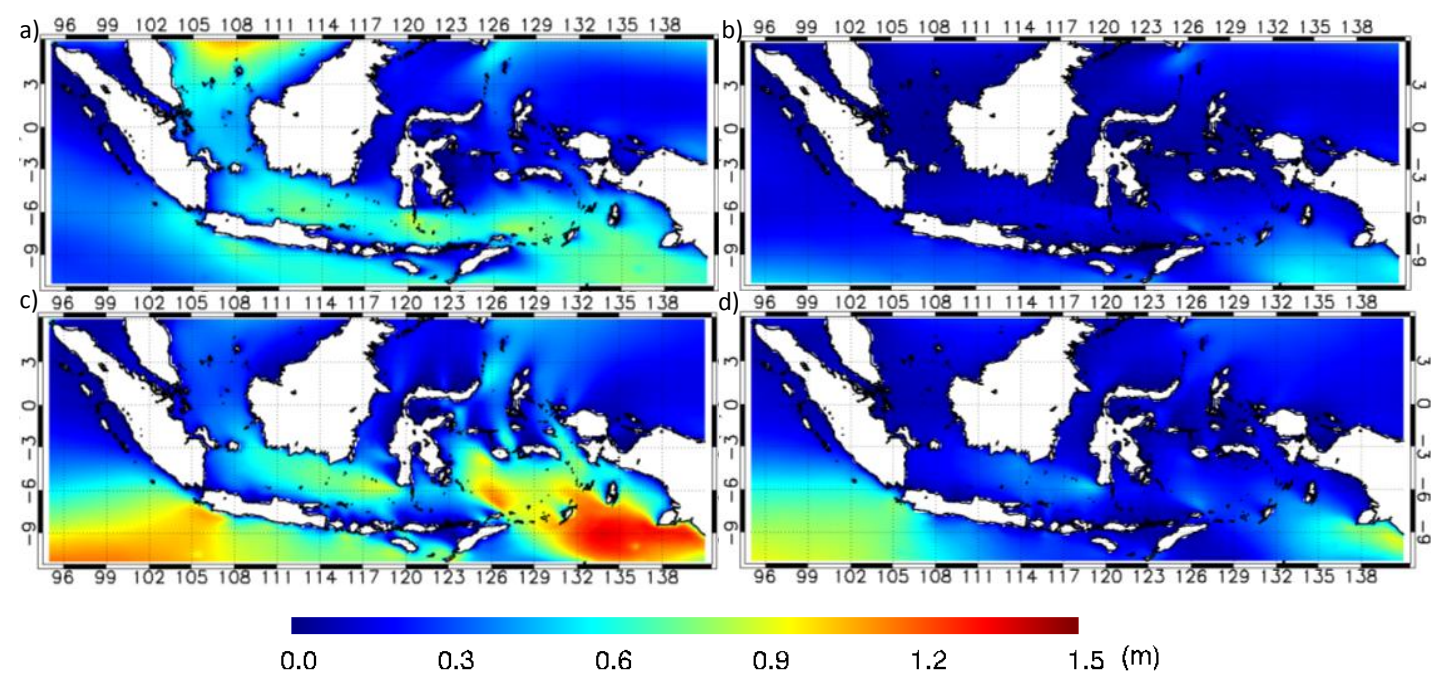

Figure 6. The same as Figure 2 but for monthly climatology of the significant wind wave height

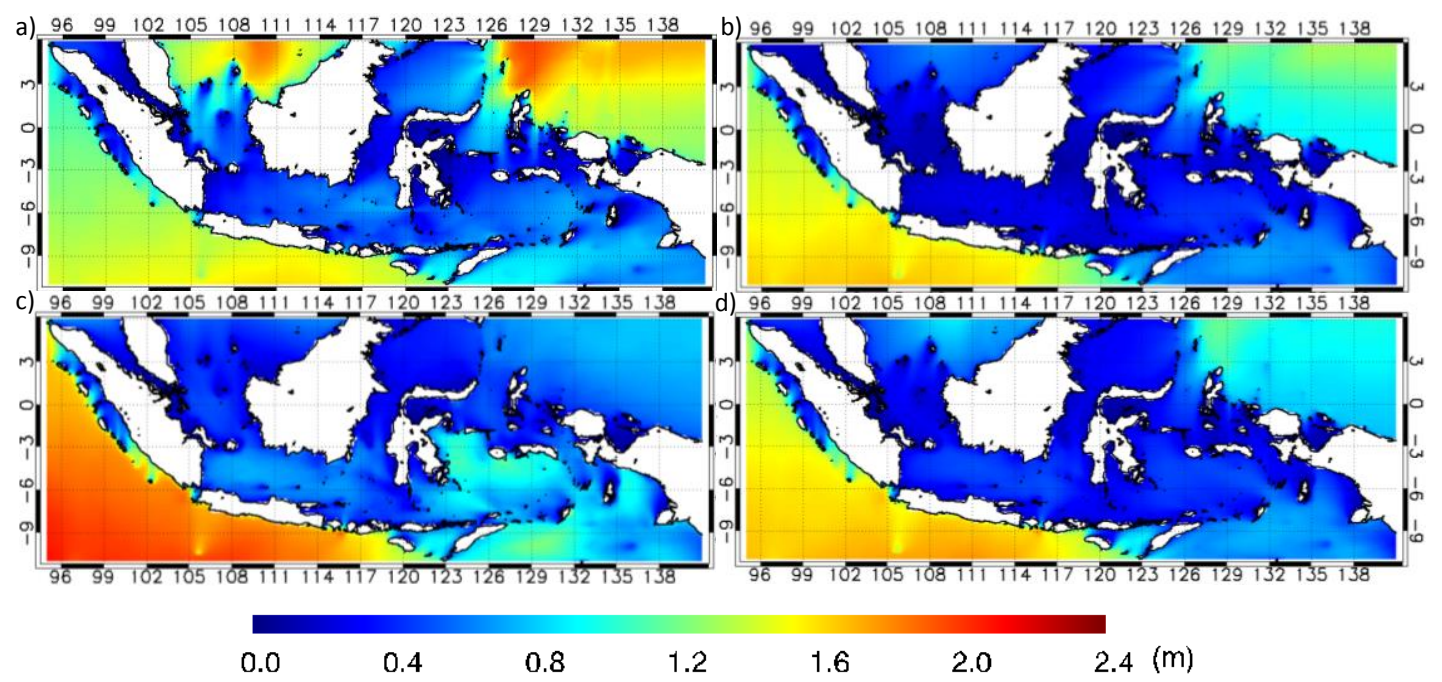

Figure 7. The same as Figure. 2 but for monthly climatology of the significant swell wave height.

However, when the wind speed is maximum during the SEM season, the $\mathrm{SWH}_{\text {sea }}$ is higher than the $\mathrm{SWH}_{\text {swell. }}$ This indicates that the direct influence of local wind to the wave generation is more dominant in these areas than the remote wind that generates swell. The characteristic of enclosed area at the Java Sea and Arafura Sea may hamper the swell propagation to the both areas. At the South China Sea, the significant swell height is higher than the significant sea height throughout the years. This indicates that the influence of remote wind is stronger than local wind in generating waves in this area. The position of the South China Sea which opens to the western Pacific Ocean may let the swell propagates from the Pacific Ocean to the South China Sea.

At the areas of Pacific Ocean and Indian Ocean, only the variability of $\mathrm{SWH}_{\text {sea }}$ follows the variability of wind speed. The variability of the $\mathrm{SWH}_{\text {swell }}$ is independent from the variability of wind speed. At the Pacific Ocean (Indian Ocean), there is only 1 peak of the maximum $\mathrm{SWH}_{\text {swell }}$ which occurs in January (July). In contrast, the peak of maximum wind speed at the Pacific Ocean and Indian Ocean occur twice a year. The magnitudes of $\mathrm{SWH}_{\text {swell }}$ are also much larger than the $\mathrm{SWH}_{\text {sea }}$ for both areas. This indicates that remote wind forcings play important role to determine the characteristics of wave at both areas than the local wind. Suciaty (2018) explained that the magnitude of the swell is larger than the sea especially at the open ocean. The wider area without obstacles, the higher swell generated. Swell can propagate hundreds kilometers from its origin area of generation. As example by Habibie et al. (2013) who simulated the extreme wave event at the southern Java on 4-10 May 2007. The strong tropical cyclone in Cape of Hope, southern 
of Africa caused persistent wind by more than 22 m.s ${ }^{1}$ speed. The wave generated by this strong wind propagated toward Indonesia waters and generated extreme swell wave by more than $3 \mathrm{~m}$ over the western coast of Sumatra, the southern coast of Java to Flores which face the Indian Ocean. Therefore, the swell at the open oceans is higher than swell at the inner seas. These facts also explain the incongruity between the wind speed and SWH at Indian Ocean and Pacific Ocean as mentioned in the previous section.

The spatial distributions of the $\mathrm{SWH}_{\text {sea }}$ and the $\mathrm{SWH}_{\text {swell }}$ are presented at Fig. 6 and 7, respectively. The spatial pattern of the $\mathrm{SWH}_{\text {sea }}$ follows the spatial pattern of wind speed. In the areas where wind speed is strong the $\mathrm{SWH}_{\text {sea }}$ is also high, and vice versa. The high $\mathrm{SWH}_{\text {sea }}$ is majorly located at the inner seas which become the main path of the monsoon wind from the South China Sea to Arafura Sea with the magnitude by more than $0.6 \mathrm{~m}$. At the NWM season, the maximum $\mathrm{SWH}_{\text {sea }}$ is located at the South China Sea while during SEM season, it is located at the Arafura Sea. During the transition seasons, the magnitude of $\mathrm{SWH}_{\text {sea }}$ is low which corresponds to the low wind speed. At the open oceans, only at the Indian Ocean during SEM and Transition II seasons the $\mathrm{SWH}_{\text {sea }}$ can reach more than $0.6 \mathrm{~m}$. This also corresponds to the magnitude of SEM wind which propagates not only through the main path of monsoon but also along the southern coast of Lesser Sunda Islands to Java Island.

Different with $\mathrm{SWH}_{\text {sea, }}$ the spatial pattern of $\mathrm{SWH}_{\text {swell }}$ shows that the high $\mathrm{SWH}_{\text {swell }}$ by more than $1.5 \mathrm{~m}$ is located at the open seas and occurs throughout the years. At the inner seas, the high $\mathrm{SWH}_{\text {swell }}$ only occurs during NWM (SEM) season at the South China Sea (Arafura Sea and Banda Sea) which indicates the capability of the $\mathrm{SWH}_{\text {swell }}$ to infiltrate to the inner seas during the peak of NWM and SEM season. The magnitude of $\mathrm{SWH}_{\text {swell }}$ is also more than $\mathrm{SWH}_{\text {sea }}$ in general.

\section{Conclusion}

The variability of wave within the Indonesian seas and its relation with the surface wind speed has been studied by using the combination of reanalysis and remote sensing data. At the inner seas (i.e., the South China Sea, Java Sea, Flores Sea, Banda Sea and Arafura Sea), the variability of SWH is majorly influenced by the variability of the speed of monsoon wind. The maximum SWH during NWM season is located at the South China Sea while during SEM season is at Arafura Sea. This indicates that the wind wave (sea) is dominant at the inner seas. At the open seas (i.e., Pacific Ocean and Indian Ocean) the variability of SWH less corresponds to the the speed of monsoon wind. The remote wind forcings control the wave variability in the open ocean area. This indicates that swell is dominant at the open seas. At the inner seas, the high $\mathrm{SWH}_{\text {swell }}$ can penetrate to the South China Sea (Arafura Sea and Banda Sea) during NWM (SEM) season. In general, the magnitude of $\mathrm{SWH}_{\text {swell }}$ is also more than $\mathrm{SWH}_{\text {sea }}$ within the Indonesian seas.

\section{Acknowledgement}

GLOBAL_REANALYSIS_WAV_001_032 is provided by Marine Copernicus at https:// resources.marine.copernicus.eu/?option $=$ com_csw \&view=details\&product_id=GLOBAL_REANALYSIS_ WAV_001_032. Anindya Wirasatriya thank to Universitas Diponegoro for the research grant no: 185 98/UN7.6.1/PP/2021

\section{References}

Alifdini, I., Shimada, T. \& Wirasatriya, A.. 2021. Seasonal Distribution and Variability of Surface Winds in the Indonesian Seas using Scatterometer and Reanalysis Data. Int. J. Climatol., 41 (10): 4825-4843. doi: 10.1002/joc.7101

Figa-Saldaña, J., Wilson, J.J.W., Attema, E., Gelsthorpe, R.V., Drinkwater, M.R. \& Stoffelen, A. 2002. The Advanced Scatterometer (ASCAT) on the Meteorological Operational (MetOp) Platform: A Follow on for European Wind Scatterometers. Can. J. Remote. Sens., 28(3): 404-412. doi: 10.558 9/m 02-035.

Habibie, M.N., Permana, D.S. \& Suratno. 2013. Simulasi Gelombang Ekstrim Akibat Swell Di Indonesia Menggunakan Model Wavewatch-III. J. Meteorologi dan Geofisika, 14(2): 99-108. doi: 10.31172/jmg.v14i2.159

Habibie, M.N., Fitria, W. \& Sofian, I. 2018. Kajian Indeks Variabilitas Tinggi Gelombang Signifikan di Indonesia. J. Segara, XIV(3): 159-168. doi: 10.15578/segara.v14i3.6650

Hadi, S. 2007. Laut Indonesia, ITB dan Pembangunan Bangsa Berbasis Kelautan. Pidato IImiah Guru Besar Institut Teknologi Bandung.

Hardjono, S. 2018. Analisa Ketinggian Gelombang yang Sesuai untuk Pengoperasian Kapal Cepat Rudal 60m di Perairan Indonesia. Warta Penelitian Perhubungan, 30(1): 43-58. doi: 10.25104/warlit.v30i1.635

Kurniawan, R., M. N. Habibie \& Suratno. 2011. Variasi Bulanan Gelombang Laut Di Indonesia. J. Meteorologi dan Geofisika, 12(3): 221-232. doi: 10.31172/jmg.v12i3.104

Kurniawan, R., Habibie, M.N. \& Permana, D.S. 2012. Kajian Daerah Rawan Gelombang Tinggi Di 
Perairan Indonesia. J. Meteorologi dan Geofisika, 13(3):201-212. doi: 10.31172/jmg.v13i3. 135

Law-Chune, S. 2019. Product User Manual For Global Ocean Waves Multi Year Product GLOBAL_REANALYSIS_WAV_001_032. Marine Copernicus eu. https://resources.marine. copernicus.eu/documents/PUM/CMEMS-GLO-PUM-00 1-032.pdf

Law-Chune, L., Aouf, L., Bruno, L. \& Dalphinet, A. 2020. Quality Information Document: Global High Resolution Production Centre GLOBAL_REANALYSIS_WAV_001_032.Marine Copernicuseu. https://resources.marine.copernicus.eu/docum ents/QUID/CMEMS-GLO-QUID-001-032 .pdf

Purbani, D., Salim, H.L., Kusuma, L.P.A.S.C., Tussadiah, A. \& Subandriyo, J. 2019. Ancaman Gelombang Ekstrim Dan Abrasi Pada Penggunaan Lahan Di Pesisir Kepulauan Karimun Jawa (Studi Kasus: Pulau Kemujan, Pulau Karimun Jawa, Pulau Menjangan Besar Dan Pulau Menjangan Kecil). J. Kelautan Nasional, XIV(1): 33-45.

Setiawan, R.Y. \& Habibi, A. 2010. SST cooling in the Indonesian Seas. IImu Kelautan: Indonesian
Journal of Marine Sciences, 15(1): 42-46. doi: 10.14710/ik.ijms.15.1.42-46

Suciaty, F. 2018. Transformasi Gelombang Swell Dan Gelombang Angin Di Perairan Selatan Bali. RekaRacana: J. Teknil Sipil, 4(3):28-39. doi: 10.26760/rekaracana.v4i3.28

Susanto, R.D., Moore, T.S. \& Marra, J. 2006. Ocean color variability in the Indonesian Seas during the seawifs era. Geochem. Geophys. Geosyst. 7(5): 1-16. doi: 10.1029/2005GC001009

Verhoef, A. \& Stoffelen, A. 2013. ASCAT coastal winds validation report, v1.5, May 2013, Technical Note SAF/OSI/CDOP/KNMI/TEC/RP/176, http: //projects.knmi.nl/scatterometer/publicca tions/pdf/ASCAT_validation_coa.pdf

Wirasatriya, A., Setiawan, R.Y. \& Subardjo, P. 2017. The effect of ENSO on the variability of chlorophyll-a and sea surface temperature in the Maluku Sea. IEEE J. Sel. Top. Appl. Earth Obs. Remote Sens., 10(12):5513-5518. doi: 10.1109 /JSTARS.2017.2745207. 